\title{
OLD AND NEW HORNS OF THE PRONG-HORNED ANTELOPE
}

\section{By Vernon BaILey}

\section{[Plate 8]}

The fact that our so-called antelope sheds and renews his horns each year has come at some time as a distinct surprise to every student of mammals - it has seemed to him almost impossible of belief and difficult to explain. Much time and space have been devoted to the study of the shedding and renewing of the hollow horn of this animal, and it is still safe to assume that we do not know all about the process. The history of our knowledge in regard to it presents an interesting chapter of doubt, disbelief, and discussion.

For over thirty years I have been for part of almost every season over some of the antelope country and have followed the herds on their summer, winter, spring, and fall ranges. I have found many skulls and skeletons, but never until recently have I found, or heard of any one finding, in the open country, a shed horn of this animal. In Yellowstone National Park, on April 7, 1916, at the edge of a melting snow bank near Blacktail Creek, I picked up a fair sized horn of a buck antelope chat evidently had been dropped in the soft snow of the preceding fall or early winter and thus was protected from coyotes until the snow melted away. It was wet and soft and leathery about the base and had the strong hartshorn (ammonia like) odor characteristic of these horns. It could not have remained uncovered very long without being found by the keen-nosed coyote, who, being in the usual hungry condition, would certainly have made a partial lunch on its edible base and probably buried the rest to become more mellow with time and moisture. This seems the most reasonable explanation for the scarcity of shed antelope horns. The horn was carefully wrapped in a handkerchief, brought to camp, and dried until hard; it was then photographed and placed in the Biological Survey collection in the National Museum. The photograph shows imperfectly some of the long white hairs lining the base of the hollow horn. These hairs had pulled part way out of the shell as it had loosened from the bony core to make room for the growth of its successor, and while they show only at the edge in the illustration, they really cover the inner surface of the horn for a considerable distance.

On March 9 of the same year I found a fully grown young buck antelope that had been killed and partly eaten by coyotes. It had 


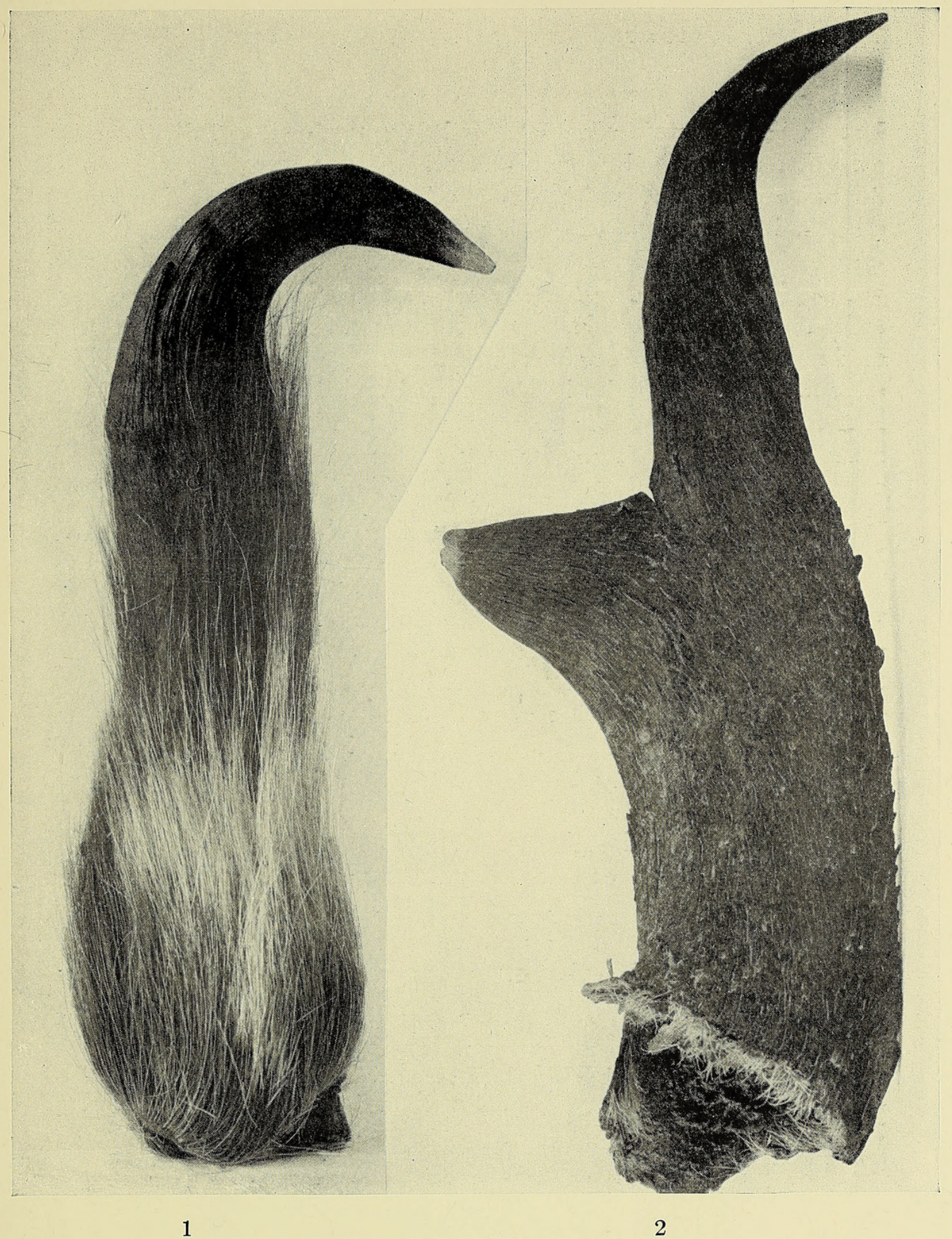

Fig. 1. New Growing Horn of Male Antelope, with Hardened Tip and Soft, | Hairy Base, TaKen March 9

Beginning of prong shown by knob on left near base. Reduced from $6 \frac{3}{4}$ inches in a straight line from top of curve to base.

Fig. 2. Shed Hollow Horn of Antelope Picked up April 7 at Edge of Snow-bank in Yellowstone Park Where Dropped in Fall or Early Winter

Showing much of the old hair at edges and inside of horn, and traces on outer surface. Reduced from $10 \frac{1}{2}$ inches in straight line from tip to base.

(Bailey: The Prong-horned Antelope.) 


\section{$2 \mathrm{BHL}$ Biodiversity Heritage Library}

Bailey, Vernon. 1920. "Old and New Horns of the Prong-Horned Antelope." Journal of mammalogy 1, 128-129. https://doi.org/10.2307/1373337.

View This Item Online: https://www.biodiversitylibrary.org/item/220052

DOI: https://doi.org/10.2307/1373337

Permalink: https://www.biodiversitylibrary.org/partpdf/90501

\section{Holding Institution}

Smithsonian Libraries

\section{Sponsored by}

Biodiversity Heritage Library

\section{Copyright \& Reuse}

Copyright Status: Not in copyright. The BHL knows of no copyright restrictions on this item.

This document was created from content at the Biodiversity Heritage Library, the world's largest open access digital library for biodiversity literature and archives. Visit BHL at https://www.biodiversitylibrary.org. 